\title{
OBITUARY: MARK ALEXANDROVICH KRASNOSEL'SKII (April 27, 1920 - February 13, 1997)
}

One of the founders of nonlinear functional analysis, Mark Alexandrovich Krasnosel'skii, passed away at the age of 77 working at his desk in his Moscow flat on February 13. He was the author of hundreds of papers (including a good dozen in 1996) and twelve research monographs translated into many languages. Mark Krasnosel'skii had amazingly broad scientific interests; his work opened new horizons in classical functional analysis, oscillation theory, numerical methods, variational problems, the mathematical theory of hysteresis and other areas. He was a superb teacher, an energetic scientific organizer and the creator of a mathematical school known worldwide. More that a hundred of his students are now working in different areas of pure and applied mathematics all over the world.

Mark Krasnosel'skii had a distinguished personality: straightforward and uncompromising in matters of principle but always open-minded and ready to help anyone. He was an indefatigable hard worker. The driving energy of Mark Krasnosel'skii inspired his colleagues and students. A big man and great mathematician left this world. His life and his scientific achievements will take some time to fully appreciate. We are saddened at the loss of our much beloved teacher and express our sympathy to his large family.

NIKOLAI A. BOBYLEV

Institute for Control Sciences

65 Profsojuznaja St.

Moscow 117806 , Russia

e-mail:bobylev@ium.ips.ras.ru
VICTOR S. KOZYAKIN

Institute of Information

Transmission Problems

Russian Academy of Sciences

19 Ermolovoy str.

Moscow 101447, Russia

e-mail:kozyakin@nov.ippi.ras.ru
ALEXEI V. POKROVSKII

School of Computing and

Mathematics

Deakin University, Geelong

Victoria 3217, Australia

e-mail:alexei@deakin.edu.au
BORIS N. SADOVSKII

Flat 27, House 7

Fridrich Engels St.

Voronezh, 394000, Russia

e-mail:ger@gela.vrn.ru 


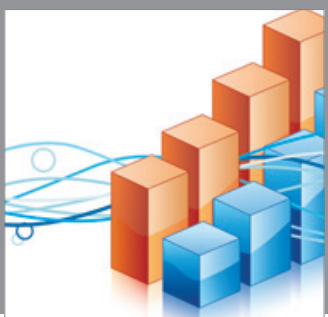

Advances in

Operations Research

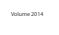

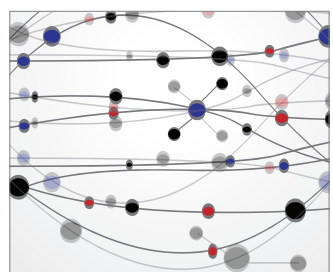

\section{The Scientific} World Journal
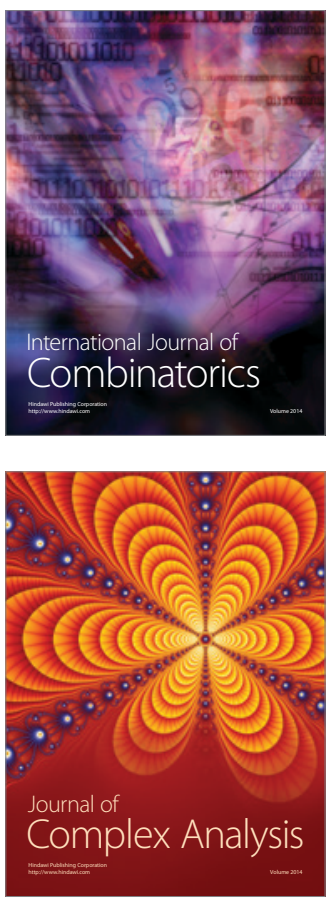

International Journal of

Mathematics and

Mathematical

Sciences
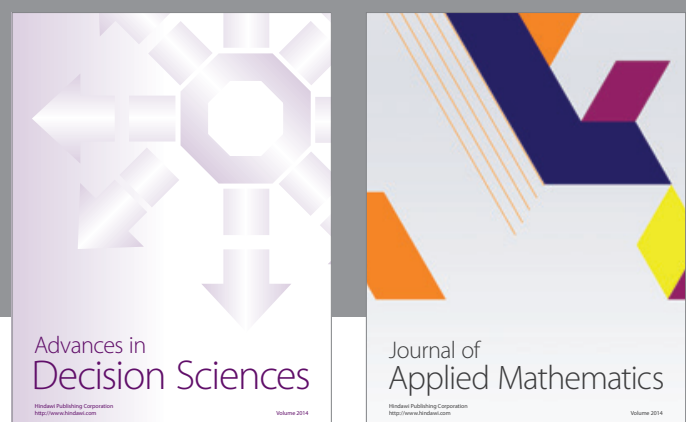

Journal of

Applied Mathematics
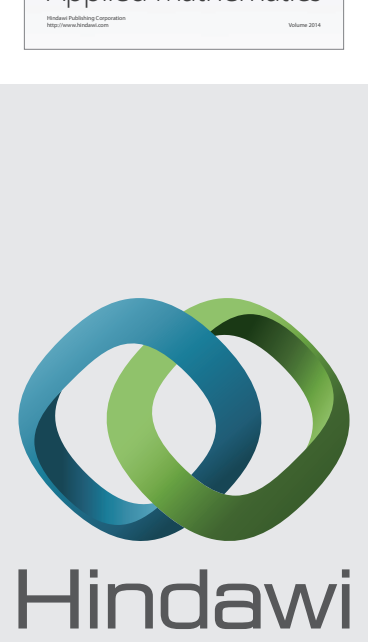

Submit your manuscripts at http://www.hindawi.com
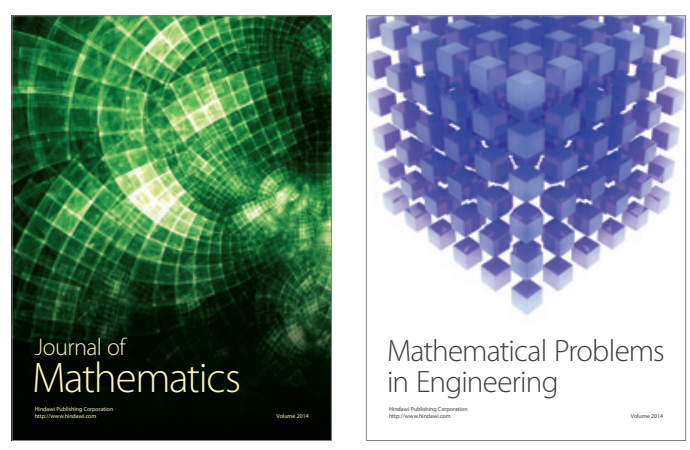

Mathematical Problems in Engineering
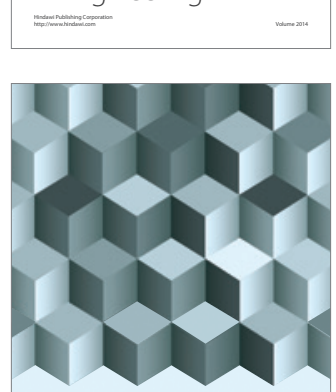

Journal of

Function Spaces
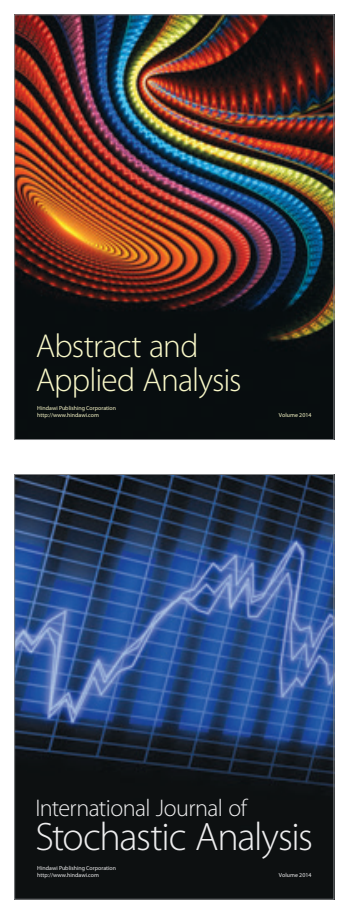

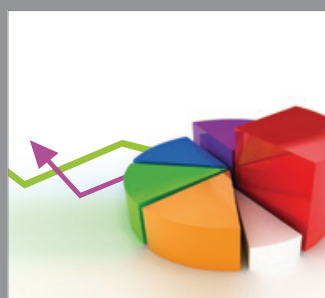

ournal of

Probability and Statistics

Promensencen
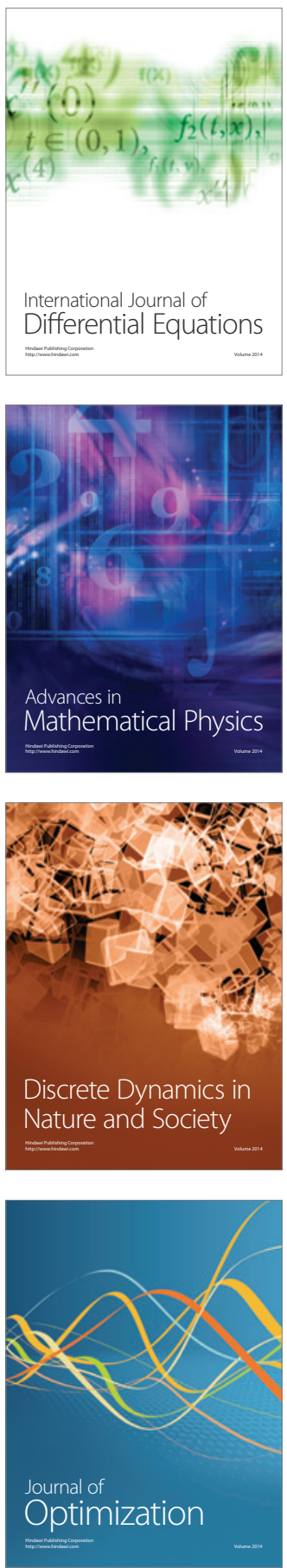